\title{
Do Work Demands and Resources Predict Work-to-Family Conflict and Facilitation? A Study of Iranian Male Employees
}

\author{
Leila Karimi · Aboulghasem Nouri
}

Published online: 12 May 2009

(C) Springer Science+Business Media, LLC 2009

Erratum to: J Fam Econ Iss

DOI 10.1007/s10834-009-9143-1

In the footnote at the bottom of the first page of the article, the name of the University for A. Nouri is incorrect. It should read University of Isfahan.

The online version of the original article can be found under doi:10.1007/s10834-009-9143-1.

L. Karimi $(\bowtie)$

School of Psychology, Deakin University,

31 Alma Road, St Kilda, VIC 3182, Australia

e-mail: 1.karimi@ymail.com

\section{A. Nouri}

School of Psychology, University of Isfahan,

Daneshgah Street, Isfahan, Iran

e-mail: a.nouri@edu.ui.ac.ir 